\title{
Universiteit
}

Leiden

The Netherlands

\section{Shirts Today, Skins Tomorrow: Dual Contests and the Effects of Fragmentation in Self-Determination Disputes}

Cunningham, K.; Bakke, K.M.; Seymour, L.J.M.

\section{Citation}

Cunningham, K., Bakke, K. M., \& Seymour, L. J. M. (2012). Shirts Today, Skins Tomorrow: Dual Contests and the Effects of Fragmentation in Self-Determination Disputes. Journal Of Conflict Resolution, 56(1), 67-93. doi:10.1177/0022002711429697

Version: $\quad$ Not Applicable (or Unknown)

License: $\quad$ Leiden University Non-exclusive license

Downloaded from: $\quad$ https://hdl.handle.net/1887/20428

Note: To cite this publication please use the final published version (if applicable). 


\title{
Shirts Today, Skins Tomorrow: Dual Contests and the Effects of Fragmentation in Self-Determination Disputes
}

\author{
Kathleen Gallagher Cunningham ${ }^{1,2}$, \\ Kristin M. Bakke ${ }^{3}$, and Lee J. M. Seymour ${ }^{4}$
}

\begin{abstract}
While theoretical models of conflict often treat actors as unitary, most selfdetermination groups are fragmented into a number of competing internal factions. This article presents a framework for understanding the "dual contests" that selfdetermination groups engage in - the first with their host state and the second between co-ethnic factions within groups. Using a new data set of the number of factions within a sample of self-determination groups from 1960 to 2008, the authors find that competition between co-ethnic factions is a key determinant of their conflict behavior. More competing factions are associated with higher instances of violence against the state as well as more factional fighting and attacks on co-ethnic civilians. More factions using violence increases the chances that other factions will do so, and the entry of a new faction prompts violence from existing factions in a within-group contest for political relevance. These findings have implications for both theory and policy.
\end{abstract}

\footnotetext{
'University of Maryland, Department of Government and Politics, College Park, MD, USA

${ }^{2}$ Peace Research Institute Oslo, Oslo, Norway

${ }^{3}$ School of Public Policy, University College London, London, United Kingdom

${ }^{4}$ Institute of Political Science, Leiden University, Pieter de la Court gebouw, Leiden, Netherlands

\section{Corresponding Author:}

Kathleen Gallagher Cunningham, Department of Government and Politics, University of Maryland, 3 I 40 Tydings Hall College Park, MD 20742, USA

Email: kgcunnin@umd.edu
} 


\section{Keywords}

self-determination, fragmentation, conflict, cohesion, ethnicity

How do internal divisions within ethnic groups seeking self-determination affect the dynamics of separatist conflicts? How does such fragmentation affect the likelihood of violent conflict within these groups? Separatist groups pose real and persistent threats to the integrity of states. Unlike groups bound together by ideological or material interests, we tend to assume that the shared ethnic identities that provide a basis for separatist mobilization reinforce the cohesion of separatist challengers. Yet, like the other contributors to this special issue, we argue that the degree of cohesiveness behind separatist groups is an empirical question to be investigated rather than taken for granted. Internal divisions within self-determination movements critically alter the interactions between these groups and the states they confront, as individual factions within larger separatist movements vie for power and survival with both the state and the other co-ethnic factions.

The dominant approach in many studies of civil and ethnic violence is to treat the groups involved as unitary. Disputes are thus modeled as games between unitary states and substate challengers (e.g., Toft 2003; Collier and Hoeffler 2004; Fearon 2004; Walter 2006). The influential Minorities at Risk (MAR) project (e.g., Gurr 2000), a source of data underpinning numerous large- $N$ studies on ethnic conflict, is built around ethno-political groups as the unit of analysis. Yet, the incongruities between the complex realities of civil war and our models, data, and units of analysis are conspicuous and have serious implications for our understanding of conflict dynamics. Empirically, we see that in cases as different as the Naga people's struggle in India, the Corsicans' struggle in France, and the Chechens' struggle in Russia, single selfdetermination movements are represented by a number of factions that challenge the state while simultaneously competing with one another. At the extreme, the complex patterns of conflict and cooperation among competing factions have been characterized as "[a] game of pickup basketball - a tournament where you never knew which team you'd be on when the next game got underway. Shirts today, skins tomorrow" (Filkins [2008], on Afghanistan). Separatist disputes are rarely dyadic. Instead, they are "complex and ambiguous processes" that lead to important shifts and realignments within and between identity groups (Kalyvas 2003, 475).

Recognizing that groups are not unitary, a variety of scholars (including the contributors to this special issue) have begun to examine the more complex nature of these actors. Computational models employ multiactor scenarios to understand how the number and heterogeneity of actors affect strategies and outcomes in civil wars (e.g., Bhavnani and Ross 2003; de Marchi 2005; Bennett 2008; Cederman 2008; Findley and Rudloff forthcoming). A few quantitative studies have begun to use new data on fragmentation to explore how divisions within identity groups affect civil war outcomes. Cunningham (2007), for 
instance, shows that internal fissures complicate a group's bargaining with the central government as its leadership cannot credibly commit to peace and change the incentives of states bargaining with challengers.

The most substantial body of work in this new research agenda involves close empirical studies of the inner workings of armed groups and their relationship to one another, their local communities, and the states they challenge (e.g., Stedman 1997; Varshney 2002; Beissinger 2002; Wood 2003; King 2004; C. Kalyvas 2006; Weinstein 2007; Pearlman 2009). A related literature examines cohesion and unity in armed groups as a dependent variable (Johnston 2008). In turning attention to the causes and consequences of internal divisions within rebel groups and ethnonationalist movements, this literature highlights the multiple agendas of participants and the ways these create complex patterns of alliances and conflict. A key lesson is that understanding violence requires disaggregating cases and looking beneath any given conflict's so called master cleavage.

These studies have generated a set of findings with far-reaching implications for the study of conflict, recasting important debates by disaggregating conflict dynamics and the actors involved. Yet, because many of these findings have emerged out of research designs rooted in careful case studies of particular conflict settings, they involve restricted scope conditions and limited claims to generalizability. At the same time, despite these important advances, the most influential large- $N$ models of ethnic and civil violence (such as Fearon and Laitin 2003; Collier and Hoeffler 2004; Hegre and Sambanis 2006) ignore actor fragmentation. ${ }^{1}$

This article provides a framework for thinking about how fragmentation affects conflict processes and tests this framework in a large- $N$ analysis. We show what is lost in ignoring variation in the cohesion and fragmentation of groups struggling for self-determination and empirically examine the effects of fragmentation across a number of self-determination disputes. In doing so, we move the study of fragmentation forward in two critical ways. First, we divorce the concept of fragmentation from particular historical settings. We develop a general theory explaining how variation in the cohesion of substate challenging groups affects conflict dynamics. Our theory, the "dual contest" framework, emphasizes how individual factions participate simultaneously in two competitions: first against the state they challenge and, second, with other co-ethnic factions. Each of these contests involves different stakes and generates unique incentives related to the use of violence. In particular, we argue that the second contest pits different co-ethnic factions against each other in a struggle over political relevance.

Second, we demonstrate the importance of competition between factions within the same self-determination movement. Even studies that highlight fragmentation in a specific dispute generally fail to assess its importance relative to other variables. We offer a series of hypotheses about the consequences of within-group fragmentation on several processes central to struggles for self-determination, including the probability of violence in the larger struggle with the state and the targets of violence within the group (whether violence is directed at other co-ethnic factions and/or 
co-ethnic civilians). Thus, rather than the typical research focus on one dependent variable, we examine how the same independent variable - fragmentation of a selfdetermination group - affects different dependent variables. By considering the dual contest that each faction within a group faces, we contribute to explanations of not only how and when self-determination conflicts turn violent but also when and why violence sometimes turns inward, targeting members of the ethnic group in whose name the movement is fighting.

We test our hypotheses at the faction-level, rather than the typical focus on the ethno-political group, and employ new data to examine the behavior of specific factions within the disputes. The faction-level analysis allows for direct tests of hypotheses about how factions behave. This is an important advance. Because they use groups or conflicts as the unit of analysis, even relatively disaggregated studies of conflict still focus on the aggregated outcomes of multiple decision-making processes that take place across a variety of internal factions. When we consider the divisions within self-determination groups - and the ability of these factions to operate independently from one another-we find that "violence" by the group can look quite different across cases. Some selfdetermination groups contain only one faction engaging in violence, while others are peaceful. In other cases, divided groups are comprised solely of factions using violence. Among some groups in which internecine conflict is rife, factions target rivals within the ethno-political group rather than directing their violence at the state. Without an exploration of the inner workings of the group, a generic observation of violence appears equivalent across what are in fact very different sets of circumstances.

Our findings reveal that interfactional competition is an important and often dominant influence in the dynamics of self-determination conflicts. We find that a greater number of factions in a self-determination group increases the probability that any individual faction will turn to violence. Moreover, as more factions take part in the struggle, violence against co-ethnic civilians increases as factions direct their violence against the potential support base of their rivals, and interfactional violence increases as groups struggle for dominance in the broader self-determination struggle. These findings add important correctives to expectations deduced from large- $N$ studies, formal models, and case studies focused only on the competition between the state and separatists. Indeed, our findings suggest that one cannot adequately explain conflict dynamics on the basis of group and country characteristics while ignoring the effects of fragmentation within nonstate actors.

The article proceeds in three parts. First, we discuss the politics of group fragmentation, lay out the dual contest framework for analyzing self-determination conflicts, and develop an argument about interfactional struggles over political relevance. Second, we introduce our data set and discuss our research design, methodology, and findings. In the third and concluding section, we discuss our findings' implications for conflict theories and policies. 


\section{Dual Contests in Self-determination Disputes}

The example of the Sikhs' struggle for self-determination in India illustrates how critical factionalism is to understanding violence. The Sikhs constitute a minority population within India and are concentrated in the Punjab region in the north. In 1960, the Sikhs began to mobilize for greater self-rule, and by the mid1980s, they found themselves in an armed struggle against the Indian state. In the late 1980 s-early 1990 s, at the height of the violent conflict, the Sikh movement was highly divided internally. Indeed, several factions of the political party Akali Dal and a number of militant groups were fighting on behalf of the Sikh population. The aims of these factions varied; some were pursuing greater autonomy within India, while others were seeking an independent Sikh state. Their tactics also varied, with some working through the political system and others resorting to violence.

In 1985, the central actor representing the Sikhs was the Akali Dal faction under the leadership of Sant Harchand Singh Longowal. While Akali Dal had never commanded uniform support from the Sikhs, Akali Dal under Longowal was supported by about 27 percent of Punjab's voters (about 60 percent of which were Sikh), and was therefore considered a legitimate representative of the group among a substantial share of Punjab's Sikhs. The central government in Delhi chose to negotiate with Akali Dal, and in June 1985, Sant Longowal and Prime Minister Rajiv Gandhi reached an agreement on autonomy.

The Rajiv-Longowal Accord was never implemented. The failure accelerated a process of actor fragmentation within Punjab. Simmering discontent within Akali Dal and among the Sikh population led to a proliferation of Akali factions and militant groups, all claiming to represent the Sikhs' interests (Bakke 2010). Indeed, the failure of the Rajiv-Longowal accord created space for a number of factions that had been largely irrelevant (neither negotiation partners of the central government nor widely supported by Punjab's population). Both Sikh and Hindu civilians were targets in the interfactional struggle that ensued. The militants were aware that their own in-fighting was at odds with the overall goals of the group vis-à-vis the central government, and militant leaders publicly decried factionalism as diverting the group from its struggle against the state (Judge 2005, 210).

Thus, the conflict in Punjab must be understood not only as a contest between the Sikhs and the Indian state but also as a contest among different Sikh factions. The Sikh case is not unique, and it highlights the need to look at the complexity of the internal politics of groups challenging the state. To understand the effects of fragmentation, we need to approach the politics of self-determination as disputes between states and separatist groups wherein the "group" is often a collection of factions. A group, in this sense, is a population with a shared ethno-nationalist identity. Each group is comprised of "factions," which are organizations that claim to represent the interests of the group in the struggle for greater self-determination. Factions can be armed groups, paramilitary organizations, political parties, or civic 
organizations. Their defining characteristic is that they attempt to influence the struggle for self-determination. But how they go about that in practice, and especially whether they use violence and how so, is the subject of this study.

Individual factions in self-determination disputes are engaged in two simultaneous contests, each of which has consequences for how conflict unfolds. First, self-determination challengers engage the state to achieve their collective policy aims. This competition generally centers on how much political control groups will have over their own affairs. In Punjab, for instance, Sikh organizations wanted greater autonomy or independence from India. Second, separatist challengers also compete with factions of the same ethnic group (i.e., co-ethnic factions) to maintain or increase their political relevance in the competition with the state. In Punjab, this was dramatically illustrated by the emergence and escalation of fighting between factions when Akali Dal was weakened by the failed settlement in 1985.

These two contests are about different things. The first contest focuses primarily on what we can think of as public goods that benefit the group as a whole. All Sikh factions pursuing greater autonomy would benefit from achieving that goal, insofar as many dimensions of self-determination are nonrivalrous and nonexcludable. In contrast, the second contest is primarily about power and material goods that benefit individual factions and are not shared with the group as a whole. Regardless of any public goods that emerge for the group from either a settlement or victory, factions that have prominent positions within the group stand to gain in their own right. These gains, which we can conceive of as private and club goods, take the form of political power, monetary payoffs, and material gains. They are essentially selective incentives, available only to those that participate in the collective struggle (Popkin 1988; Lichbach 1994), or, to extend that thinking, only to those at the table when the spoils of collective struggle are distributed. For example, the Eritrean People's Liberation Front (EPLF) emerged from a fragmented Eritrean resistance movement in the 1970 s by violently eliminating other factions competing for leadership of the Eritrean movement. The EPLF and its leaders were thus well placed to reap the private and club good benefits that came from the achievement of independence in 1993. Likewise, the Oslo Accord's recognition of Yasir Arafat's Palestinian Liberation Organization as the authoritative representative of the Palestinian people allowed Arafat to monopolize the distribution of jobs, inflows of foreign aid, and revenues in the Palestinian Authority (Pearlman 2009, 98). Thus, factions have two sets of motivations that map onto these two contests: they seek public goods for the group in the form of self-determination, but they also seek control over private goods that benefit faction leaders and supporters, as well as club goods that will not be shared across factions.

To obtain these private and club goods, individual factions seek to be politically relevant in the larger struggle. Politically relevant factions are those that other actors in the dispute must engage with, either militarily or politically. Political relevance 
refers to the position of the faction vis-à-vis the state, rival factions, and the population it claims to represent. The state must contend with a politically relevant faction - combating it militarily, countering it politically, and perhaps even negotiating with it. Empirically, political relevance is a continuum, ranging from factions that scramble to survive to those that dominate the struggle. The competition for political relevance among these factions is driven by the benefits of controlling territory and people during the struggle, and by individual factions' desire to benefit from any settlement attained at the negotiating table or on the battlefield.

At times, these two contests will generate divergent interests for individual factions, which can lead to behavior that appears irrational if we consider only the larger struggle with the state. For example, without attention to fragmentation, it is difficult to make sense of infighting between factions with similar aims, or of violence spoiling agreements that would give the group substantially more control over its own affairs. Indeed, while the first contest focuses on achieving concessions for the group, the pursuit of these policy aims can be at odds with any one faction's incentive to maintain political relevance. A settlement broadly consistent with the policy aims of a faction — and the group as a whole — might provide greater benefits to the leader and followers of a different faction because the other faction is the recipient of direct negotiation with the state. In this case, factions may engage in spoiling violence when it is clearly at odds with their preferences in the larger dispute with the state but consistent with the within-group struggle for political relevance (Pearlman 2009).

The importance of the second contest depends on the number of factions in the group challenging the state. All else being equal, a greater number of factions should generate more intense competition for political relevance. Due to the zero-sum nature of political relevance, a greater number of competing factions will diminish the ability of any individual faction to legitimately claim that it represents the interests of its group. More factions present the state with more potential bargaining partners, increasing the chance that any individual faction could be excluded if there is a settlement. Whether the group gains power through concessions or victory, a greater number of factions participating in the process diminishes each faction's share of benefits from the struggle.

This second contest has important implications for the study of separatist violence. Theorizing the contest between factions helps us to understand strategies and outcomes at the faction level, specifically, the conditions under which we expect individual factions to use violence and where that violence will be directed. We develop a set of hypotheses that build on the logic of our dual contest framework, with the struggle for political relevance as the mechanism driving strategic decision making. We examine three dependent variables: a faction's violence in the larger struggle with the state; a faction's violence against co-ethnic factions from the same group; and its violence against co-ethnic civilians from the same group. Each of these variables represents central questions in the study of conflict that should be affected by fragmentation. 


\section{Violence against the State}

Factions in self-determination groups compete with each other for political relevance, which can essentially be obtained from either above or below. States make some factions relevant by selecting them as negotiating partners. However, factions can become relevant even if they are ignored by the state, for instance by gaining support among their constituent population, contesting state authority, or eliminating rivals. Violence is one strategy that factions can use to do this. Factions that use violence impose costs on the state and so may be more likely to be incorporated into some process of negotiation (Fearon 1995; Powell 1999). Additionally, the use of violence may increase a faction's popularity with hard-line members of the community. This can lead to a dynamic of escalatory outbidding, in which factions use violence to establish their nationalist credentials, leading other factions to resort to violence (Rabushka and Shepsle 1972; Rothschild 1981; Horowitz 1985; Kaufman 1996; Snyder 2000; Walter and Kydd 2002; Bloom 2004; Toft 2007).

Based on this logic, why do not all groups use violence? Violence is a risky strategy, which can lead to reprisals from the state, including the potential for the faction to be eliminated and a decline in international support. Certain factions may adhere to peaceful tactics either due to ideological convictions, strategic beliefs about the utility of nonviolence, or to remain relevant by carving out a niche as a peaceful faction, for example, as a legal opposition party. However, as the competition within the group increases (i.e., as there are more factions vying for relevance), the incentives for factions to use this risky strategy also increase. We would expect, then, to see greater use of violence by factions when there are more factions in the selfdetermination group.

Hypothesis 1a: The greater the number of other competing factions, the more likely each faction is to resort to violence in their struggle against the state.

While Hypothesis 1a reflects the effect of competition among factions on the use of violence, we also expect that the intensity of the second contest is likely to be greater when other factions are using violence. Thus, when other factions use violence, the second contest generates stronger incentives for individual factions to use violence to maintain their political relevance. The logic of outbidding leads to a similar prediction - that factions are likely to respond to the use violence by others factions by increasing their use of violence.

Hypothesis $1 b$ : The greater the number of other competing factions using violence, the more likely each faction is to resort to violence in its struggle against the state.

\section{Violence against Co-Ethnic Factions}

High interfactional competition also makes it more likely that violence will occur between factions within the group. While many of these factions pursue the same 
(or at least similar) policy aims and represent the same ethnic group, they also constitute a threat to one another in their quest for political relevance and access to the rewards that come with it. This competition between factions can take the form of internecine violence as factions attempt to bolster their own ability to negotiate with or to challenge the state to the detriment of other factions. We expect that as the number of competitors increases, so does the chance of violence between factions.

Violence directed at co-ethnic factions is particularly likely when there are multiple factions using violence of any type. Because factions have limited resources, they have to consider whether they should use those resources for engaging the state or for competing with co-ethnic factions. Factions are most likely to turn their attention and resources inward to factional politics when other factions are already using violence, which can increase their standing vis-à-vis the state and the local population (if outbidding is successful). Indeed co-ethnic factions often pose a more dangerous threat than state security forces (Lyall 2010), providing further incentives to attack rivals. Fighting other factions is risky. But the costs of not doing so can be even higher, especially in the long run, as factions opting to stand on the sidelines risk political irrelevance or extinction.

Hypothesis 2a: The greater the number of other competing factions, the more likely each individual faction will target other co-ethnic factions.

Hypothesis $2 b$ : The greater the number of other competing factions using violence, the more likely each individual faction will target co-ethnic factions.

\section{Violence against Co-Ethnic Civilians}

Internecine conflict can also be directed toward co-ethnic civilians. In particular, fragmentation within a community can turn violence inward as factions terrorize civilians as a means to control the population they claim to represent and to punish those that support competing factions (Humphreys and Weinstein 2006; Kalyvas 2006; Weinstein 2007). In Southern Sudan, for instance, a split in the main rebel group, the Sudan People's Liberation Army, triggered a fratricidal war between southerners as the factions targeted their rivals' supporters. The people killed in the subsequent Southerner-on-Southerner violence, many of them Nuer killed by Nuer militia, far exceeded those killed by the Sudanese army (Jok and Hutchinson 1999). We expect that violence toward co-ethnic civilians will increase with a higher number of competing factions claiming to represent the group's interests. More intense competition between factions will increase the use of coercion against the civilian supporters of rival co-ethnic factions as factions work harder to maintain political relevance by weakening their rivals. Again, this may be particularly accentuated when other factions use violence if violence by some factions heightens competition.

Hypothesis 3a: The greater the number of other competing factions, the more likely it is that each individual faction will target co-ethnic civilians. 
Hypothesis $3 b$ : The greater the number of other competing factions using violence, the more likely each individual faction will target co-ethnic civilians.

\section{Research Design}

To test these hypotheses, we have collected original data on the number of factions and use of violence by factions in a random sample of self-determination groups. This data set allows us to test hypotheses about factional behavior and the consequences of fragmentation in a way that has not been done thus far, using the faction year as the unit of analysis. In this section, we present the new data. We then report the findings of the analysis, followed by a discussion of the implications.

\section{The Sample}

A key barrier to large- $N$ studies of fragmentation has been the unavailability of finegrained data across a wide range of cases. This is particularly problematic for studies that want to consider the effects of a variety of different types of actors and strategies, such as addressing the role of both nonarmed and armed actors on conflict processes. Building on Cunningham (2011), we have collected data on factions in a random sample of twenty-two ethnic groups seeking self-determination from 1960 to 2008. All of these groups have experienced some degree of militancy surrounding their self-determination claims. Our data set encompasses 242 self-determination factions within these groups, with data on 880 dispute years and more than 2,500 faction years, spanning multiple regions of the world. The random sample is drawn from the Center for International Development and Conflict Management's (CIDCM) list of self-determination groups. ${ }^{2}$ Using a random sample ensures probabilistic equivalence, in that any differences between self-determination groups in and out of the sample are unlikely to correlate with group fragmentation.

Within the groups in the sample, we include all representative factions engaged in the self-determination disputes, regardless of whether they use violence. However, the sample includes self-determination groups where some factions either engaged in civil war or employed strategies that CIDCM calls "militant politics," such as demonstrations, strikes, and even riots, but stop short of escalating to armed attacks against people (Gurr and Marshall 2003). Thus, while the sample encompasses nonviolent factions, we explicitly exclude self-determination groups with no history of militancy at all. In doing this, we follow Mahoney and Goertz's (2004) notion of the possibility principle in selecting negative cases. Rather than inflate our observations by including theoretically irrelevant cases of totally conventional politics, wherein neither the state nor self-determination factions see violence as a possibility, we select among groups in which violence is a plausible outcome.

To be included as a faction, an organization has to represent the group and make demands over an issue related to self-determination. The measure includes different 
Table I. Sample of Self-Determination Struggles and Total Factions by Group

\begin{tabular}{llcc}
\hline Country & Group & Factions $^{\mathrm{a}}$ & Years in Data Set $^{\circ}$ \\
\hline Afghanistan & Tajiks & 1 & $1996-2008$ \\
Algeria & Berbers & 7 & $1963-2008$ \\
Bangladesh & Chittagong Hill Tribals & 8 & $1972-2008$ \\
Bhutan & Lhotshampas & 1 & $1985-2007$ \\
China & Tibetans & 6 & $1960-2008$ \\
Cyprus & Turkish Cypriots & 8 & $1960-2008$ \\
Ethiopia & Afars & 4 & $1975-2008$ \\
France & Corsicans & 42 & $1966-2008$ \\
India & Bodos & 14 & $1973-2008$ \\
Indonesia & East Timor & 18 & $1974-1999$ \\
Israel & Palestinians & 22 & $1960-2008$ \\
Moldova & Gaguaz & 2 & $1989-2008$ \\
Myanmar & Kachins & 6 & $1963-2003$ \\
Myanmar & Rohingyas & 14 & $1962-1970,1975-2003$ \\
Niger & Tuaregs & 8 & $1999-2008$ \\
Nigeria & Oron & 2 & $1962-1971$ \\
Pakistan & Bengalis & 6 & $1991-2008$ \\
Russia & Chechens & 19 & $1991-2008$ \\
Russia & Tatars & 9 & $1960-2009$ \\
Sri Lanka & Tamils & 20 & $1984-2008$ \\
Turkey & Kurds & 10 & $1963-1999$ \\
Yugoslavia & Kosovar Albanians & 13 & \\
\hline
\end{tabular}

${ }^{a}$ Note that not all factions are active over the entire course of the conflict.

types of organizations, from political parties to rebel groups. To identify factions, we rely on news sources (via Keesings Record of World Events and Lexis Nexis Academic) and existing data on self-determination disputes (including the Uppsala Conflict Database and the MAR Project). The appendix includes detailed information on the coding procedure.

There is a great deal of variation in the number of factions and their behavior and strategies within these groups (both among factions and across time for particular factions). Table 1 gives an overview of the groups included in our sample, including the total number of factions to have represented each group over the course of the struggle. In our sample, all but two of the twenty-two groups have two or more factions since 1960. For example, since Chechnya declared independence from the Russian Federation in 1991, at least nineteen different factions have fought in the name of the Chechens. About 37 percent of these factions have been completely peaceful, 21 percent have engaged in violence every year of the dispute, and 42 percent have intermittently resorted to violence. Thus, we measure important variation in the strategies that factions use to pursue their aims, which allows us to capture the complex nature of interfactional relationships within these groups and examine some of the determinants of faction strategy and behavior. 


\section{Independent Variables}

The key independent variables are the yearly number of other co-ethnic factions within a self-determination struggle in each year (logged) and the yearly number of other co-ethnic factions using violence in each year (logged). ${ }^{3}$ These variables are designed to capture the intensity of the within-group competition for political relevance facing each individual faction. Ideally, we would also have information on the relative size and power of these different factions to explore the concept of political relevance in a more nuanced way. The substantial and challenging data collection this would entail is beyond the scope of this study. However, our hypotheses based on the logic of factional competition can be appropriately tested using a measure of fragmentation without information about power and size as two of the three ways that factions achieve political relevance - popular support or state selection as a bargaining partner - are not dependent on faction armed power per se. We use a natural $\log$ of the number of factions because the degree to which competition increases with the addition of one more faction may vary depending on how fragmented the group already is. For example, we would not expect the level of competition to be comparably increased when one faction joins a struggle with ten other factions as when one faction joins two others.

\section{Dependent Variables}

All dependent variables are coded on a yearly basis for each faction and are dichotomous indicators. Violence against the state is coded one if we found reports indicating that the faction uses violence (deadly or nondeadly) against the state at the national or local level, such as Chechens targeting the Russian army or local administration. ${ }^{4}$ Violence against co-ethnic factions is coded as one if we found reports of fighting between the faction and another co-ethnic faction, including nonlethal clashes. Violence against co-ethnic civilians is coded as one if the faction is reported to have targeted co-ethnic civilians.

\section{Methods and Controls}

We test each hypothesis using logistic regression, clustering the errors on the selfdetermination dispute. For all tests, we report the coefficients with standard errors and include a discussion of substantive effects of significant variables. Because factions in disputes that involve violence in one year may be more likely to see violence in the subsequent year, there is the possibility of serial autocorrelation in the data. To address this possibility, we structure the data as a binary time-series cross section, and we include a measure of the number of years since the faction engaged in the type of violence or targeting choice in each model with cubic splines (Beck, Katz, and Tucker 1998). 
We include several control variables for factors that are likely to be associated with the use of violence and with fragmentation. ${ }^{5}$ We include geographic concentration of the group, relative size of the group, and an indicator for whether the group has some local governance structure. Geographically concentrated groups are more likely to turn violent (Toft 2003) and more dispersed groups may become more fragmented. ${ }^{6}$ Relatively large groups may be more likely to use violence than very small groups if they believe they can pose a threat to the state (Posner 2004). ${ }^{7}$ Larger groups may also be more likely to have a greater disparity of preferences and identities in ways that could encourage fragmentation (Alesina and Spolaore 2003). Finally, local governing institutions could create greater unity for the group (decreasing the number of factions) and create a focal point for coordinated action, helping to overcome collective action problems. ${ }^{8}$

We also control for two features of the state: the level of democracy, measured with the Polity 2 score from Polity IV (Marshall and Jaggers 2008), and political instability, measured as at least a three unit change in Polity 2 score in a threeyear period. Democracy is often expected to have a negative effect on violence in civil wars. Yet, we would expect that it has a reverse effect on fragmentation; openness allows for the proliferation of factions as channels of nonviolent competition are available to separatists. Political instability is likely to create an opportunity for factions to challenge the state, thus increasing the use of violence (Hegre et al. 2001; Fearon and Laitin 2003; Gates et al. 2006). Political instability also generates a high degree of uncertainty about this opportunity for challenging the state, which can lead to greater fragmentation as factions assert themselves in the competition for relevance within the group (Crescenzi 1999; Regan and Norton 2005).

\section{Endogeneity Concerns}

One of the primary challenges of this study - and any study that attempts to determine the effects of fragmentation - is endogeneity. Our examination of actor fragmentation is rooted in the belief that conflict processes are complex and interactive and that we must attempt to look systematically at these complexities. In doing so, however, we highlight a variable - actor fragmentation - that is influential in determining the use of violence but is also influenced by the process of conflict surrounding it.

The interconnectedness of these factors is a reality for the study of fragmentation, and a challenge we have attempted to address in a few ways. Our use of time series data partly addresses this problem by allowing the number of factions to vary within groups over time. We assess the probability of violence (both whether violence is used and what the targets of violence are) based on the number of other factions at that time. Another specific endogeneity problem is that preferences over the use of violence may be at the root of fragmentation, so what we really capture here are factions' divergent preferences rather than strategic choices motivated by interfactional competition. To shed light on this issue, we examine Cunningham's (2011) 
Table 2. The Effect of Fragmentation on the Use of Violence against the State

\begin{tabular}{|c|c|c|c|c|}
\hline \multirow[b]{2}{*}{ Variables } & \multicolumn{2}{|c|}{$\begin{array}{c}\text { Model I Hypothesis } \\
\text { la: } \\
\text { Factions }\end{array}$} & \multicolumn{2}{|c|}{$\begin{array}{c}\text { Model } 2 \text { Hypothesis } \\
\text { Ib: } \\
\text { Violent Factions }\end{array}$} \\
\hline & Coefficient & SE & Coefficient & SE \\
\hline Number of other factions (log) & 0.16 & 0.20 & & \\
\hline Number of other violent factions (log) & & & $0.34 *$ & 0.21 \\
\hline Group geographic concentration & $0.40 * *$ & 0.20 & 0.30 & 0.20 \\
\hline Polity 2 scale & -0.01 & 0.02 & -0.02 & 0.01 \\
\hline Political instability & $-0.54^{*}$ & 0.33 & -0.51 & 0.34 \\
\hline Relative group size & 0.01 & 0.01 & 0.01 & 0.01 \\
\hline Group government & -0.03 & 0.21 & -0.01 & 0.16 \\
\hline Years since violence against the state & $-1.38^{*}$ & 0.13 & $-1.37 * *$ & 0.13 \\
\hline Constant & $-1.08 *$ & 0.56 & $-0.78 *$ & 0.43 \\
\hline Number of observations & 2,466 & & 2,466 & \\
\hline Pseudo $R^{2}$ & 0.40 & & 0.40 & \\
\hline
\end{tabular}

*Significant at the .10 level.

**Significant at the .05 level (two-tailed tests).

coding of strategy preferences at the group level. We find only two disputes in our data set, where factions explicitly demand that policy aims be achieved through violence. Although not a conclusive proof that endogeneity is not a problem, this evidence suggests that our results are not driven by factions' divergent preferences over strategy. Another possible way to address the endogeneity problem is to examine the behavior of factions as an additional faction enters the fray, which we do in Table 5 .

\section{Results}

\section{Violence against the State}

Table 2 presents the results for our hypotheses about the use of violence by factions against the state. Models 1 and 2 return positive coefficients on the logged number of other factions and logged number of other violent factions. This result is statistically significant (at the .10 level in a two-tailed test) in model 2. The greater the number of other factions using violence, the higher the probability that a particular faction will use violence, even accounting for the use of violence in the past. This indicates support for Hypothesis 1b: a greater number of other factions using violence increases the chance that any particular faction will use violence as well.

These models also suggest that factions in more geographically concentrated groups are more likely to use violence, while political instability in the country as a whole makes violence less likely. The negative sign for political instability goes contrary to our expectations. Possibly, we can take this to suggest the relative 
Table 3. The Effect of Fragmentation on Violence against Co-Ethnic Factions

\begin{tabular}{|c|c|c|c|c|}
\hline \multirow[b]{2}{*}{ Variables } & \multicolumn{2}{|c|}{$\begin{array}{c}\text { Model I Hypothesis } \\
\text { 2a: } \\
\text { Factions }\end{array}$} & \multicolumn{2}{|c|}{$\begin{array}{c}\text { Model } 2 \text { Hypothesis } \\
\text { 2b: } \\
\text { Violent Factions }\end{array}$} \\
\hline & Coefficient & $S E$ & Coefficient & $S E$ \\
\hline Number of other factions (log) & $1.26 * *$ & 0.40 & & \\
\hline Number of other violent factions (log) & & & $0.98 * *$ & 0.22 \\
\hline Group geographic concentration & $2.38 * *$ & 0.47 & $2.03 * *$ & 0.46 \\
\hline Polity 2 scale & $0.12 * *$ & 0.05 & $0.11 * *$ & 0.04 \\
\hline Political instability & -0.96 & 0.64 & $-0.99 *$ & 0.59 \\
\hline Relative group size & $-0.08 * *$ & 0.02 & $-0.06 * *$ & 0.02 \\
\hline Group government & -0.32 & 0.35 & 0.00 & 0.24 \\
\hline Years since factional co-ethnic violence & $-1.24 * *$ & 0.30 & $-1.27 * *$ & 0.31 \\
\hline Constant & $-9.03 * *$ & 1.61 & $-6.89 * *$ & 1.32 \\
\hline Number of observations & 2,308 & & 2,308 & \\
\hline Psuedo $R^{2}$ & 0.40 & & 0.40 & \\
\hline
\end{tabular}

*Significant at the .10 level.

**Significant at the .05 level (two-tailed tests).

importance of the interfactional (or second) contest that we highlight here. Instability in the country as a whole, which relates to the first contest between the group and the state, does not have a conflict-promoting role for factional decisions about the use of violence, as factions are more concerned about numerous competing factions within the group. Alternatively, the finding may suggest that factions may hesitate to engage in acts of violence in periods of rapid political change.

When we examine the substantive significance of the variables, we find that the effect of more factions using violence on the likelihood that any individual faction will use violence is large compared to other variables. Moving from the minimum to maximum values on the logged number of violent factions leads to an 8 percent increase in the predicted probability that a particular faction will use violence against the state in a particular year. ${ }^{9}$ This is a large effect compared to the effect of group concentration (a 2 percent increase) and political instability (a 3 percent decrease). ${ }^{10}$

\section{Violence against Co-Ethnic Factions}

Table 3 presents tests of our hypotheses about the use of violence against co-ethnic factions, excluding all observations where there was only one active faction (since in those cases, there is no possibility of violence against other factions).

The results in Table 3 support our expectations from Hypotheses $2 \mathrm{a}$ and $2 \mathrm{~b}$. Both the logged number of other factions and the logged number of other violent factions are statistically significant and positively associated with the likelihood that each individual 


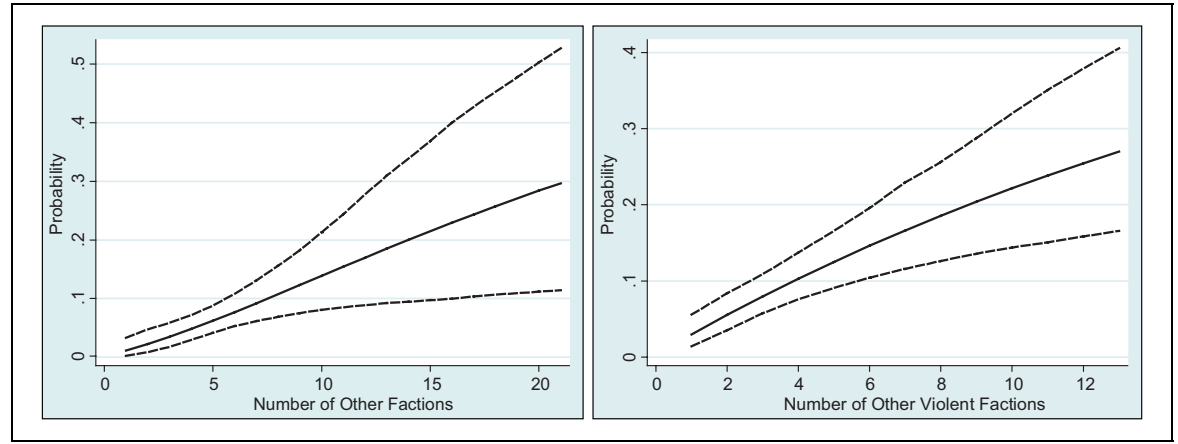

Figure I. Predicted probability of factions targeting co-ethnic factions by number of other factions (left panel) and the number of other factions using violence (right panel)

faction will use violence against co-ethnic factions. As a faction faces a greater number of potential internal rivals, the struggle turns inward against other factions representing the same group. Figure 1 shows how the predicted probability of factional fighting changes across different numbers of factions for all factions and violent factions. ${ }^{11}$

The predicted probability of each faction targeting another faction increases steadily as the number of other factions and the number of other violent factions increase. The substantive effect of adding more factions, regardless of their strategy choice, is similar. Going from the minimum to maximum values on logged number of other factions increases the likelihood of targeting of co-ethnic factions by about 28 percent. A similar change in the logged number of other violent factions leads to a 24 percent increase in the probability of a faction targeting another co-ethnic faction.

We also find that factions in more geographically concentrated groups are more likely to use violence against other co-ethnic factions, while those in relatively large groups and countries with political instability are less likely to do so. A greater degree of democracy is associated with an increased chance of fighting between factions. Comparing the effects of fragmentation to other predictors, we find a 12 percent increase in the probability of factions targeting co-ethnic factions in a given year moving from the minimum to maximum values on the Polity 2 score, while a similar change in the relative size of the group produces a 17 percent decrease in this probability. Factions in more geographically concentrated groups are 8 percent more likely to target co-ethnic factions in a given year, while those in politically unstable countries are about 5 percent less likely to do so.

The finding that factions in a more democratic setting are more likely to fight coethnic factions is somewhat surprising given the oft-cited negative association between democracy and the onset of civil wars. We suspect that increasing political openness may lead to a proliferation of new factions, in turn engendering infighting among them. Democracies invite political participation that can trigger conflict behavior as organizations overstep the boundaries of acceptable levels of debate (Vreeland 2008). Finally, 
Table 4. The Effect of Fragmentation on Violence against Co-Ethnic Civilians

\begin{tabular}{lcccccc}
\hline & \multicolumn{2}{c}{$\begin{array}{c}\text { Model I Hypothesis } \\
\text { 3a: } \\
\text { Factions }\end{array}$} & & & \multicolumn{2}{c}{$\begin{array}{c}\text { Model } 2 \text { Hypothesis } \\
\text { 3b: } \\
\text { Variablent Factions }\end{array}$} \\
\cline { 2 - 3 } \cline { 6 - 7 } Number of other factions (log) & 0.83 & 0.54 & & \\
Number of other violent factions (log) & & & & $0.72^{* *}$ & 0.34 \\
Group geographic concentration & $1.23^{* *}$ & 0.61 & & $1.03^{*}$ & 0.60 \\
Polity 2 scale & $0.10^{* *}$ & 0.04 & & $0.09^{* *}$ & 0.04 \\
Political instability & $-1.44^{*}$ & 0.76 & & $-1.48^{* *}$ & 0.75 \\
Relative group size & $-0.07^{* *}$ & 0.03 & & $-0.06^{* *}$ & 0.03 \\
Group government & -0.23 & 0.56 & & -0.02 & 0.48 \\
Years since co-ethnic violence against civilians & $-2.14^{* *}$ & 0.21 & & $-2.17^{* *}$ & 0.23 \\
Constant & $-4.74^{* *}$ & 2.00 & & $-3.52^{* *}$ & 1.49 \\
Number of observations & 2466 & & & 2466 & \\
Psuedo $R^{2}$ & 0.46 & & & 0.46 & \\
\hline
\end{tabular}

*Significant at the .10 level.

**Significant at the .05 level (two-tailed tests).

the findings indicate that, as expected, the longer it has been since a faction last used violence against co-ethnic civilians, the less likely it is to do so.

\section{Violence against Co-Ethnic Civilians}

Table 3 suggests that increased factional competition leads to a greater use of violence among factions; in Table 4, we evaluate whether factional competition also increases factions' use of violence against co-ethnic civilians.

Our expectation is that as the number of factions increases, each faction is more likely to turn violence inward toward its group in an effort to prevent members of the population from "defecting" to other factions, punish those that do, and attack the supporters of rival factions. While we find that there is a positive relationship between the number of factions and violence against co-ethnic civilians, this relationship is only statistically significant when we consider whether the other factions use violence as well, though the coefficient approaches significance for the number of other factions (model $1, p=.13$ ). The trend in the substantive effect of the number of violent factions is similar to those in Figure 1. As the number of factions using violence increases, there is a steady increase in the probability that a particular faction will target co-ethnic civilians in a given year. Moving from the minimum to maximum values on the logged number of factions produces a 9 percent increase in the likelihood of a faction targeting co-ethnic civilians in a year. This is greater than 
Table 5. The Effect of New Factions on Violence against the State and Violence against Co-Ethnics

\begin{tabular}{|c|c|c|c|c|c|c|}
\hline \multirow[b]{2}{*}{ Variables } & \multicolumn{2}{|c|}{$\begin{array}{c}\text { Model I } \\
\text { Violence against } \\
\text { the State }\end{array}$} & \multicolumn{2}{|c|}{$\begin{array}{c}\text { Model } 2 \\
\text { Violence against } \\
\text { Co-Ethnic } \\
\text { Factions }\end{array}$} & \multicolumn{2}{|c|}{$\begin{array}{c}\text { Model } 3 \\
\text { Violence against } \\
\text { Co-Ethnic } \\
\text { Civilians }\end{array}$} \\
\hline & Coefficient & SE & Coefficient & SE & Coefficient & SE \\
\hline $\begin{array}{l}\text { New faction enters in previous } \\
\text { year }\end{array}$ & $0.7 I^{* *}$ & 0.36 & $1.38 * *$ & 0.50 & $1.56 * *$ & 0.38 \\
\hline Number of factions & 0.02 & 0.03 & $0.10 * *$ & 0.04 & 0.05 & 0.05 \\
\hline $\begin{array}{l}\text { Interaction (new faction lag } \times \\
\text { number of factions) }\end{array}$ & $-0.04 * *$ & 0.02 & $-0.06^{*}$ & 0.03 & $-0.07^{*}$ & 0.04 \\
\hline Group geographic concentration & 0.27 & 0.19 & $1.73 * *$ & 0.47 & $0.97 * *$ & 0.42 \\
\hline Polity 2 scale & 0.00 & 0.01 & 0.10 & 0.05 & $0.07 * *$ & 0.03 \\
\hline Political instability & -0.37 & 0.27 & $-1.06 * *$ & 0.62 & -0.94 & 0.85 \\
\hline Relative group size & 0.00 & 0.01 & $-0.06 * *$ & 0.02 & $-0.05^{*}$ & 0.03 \\
\hline Group government & -0.11 & 0.25 & -0.32 & 0.38 & -0.06 & 0.46 \\
\hline $\begin{array}{l}\text { Years since violence against the } \\
\text { state }\end{array}$ & $-1.76^{* *}$ & 0.19 & & & & \\
\hline $\begin{array}{l}\text { Years since co-ethnic factional } \\
\text { fighting }\end{array}$ & & & $-1.94 * *$ & 0.37 & & \\
\hline $\begin{array}{l}\text { Years since co-ethnic violence } \\
\text { against civilians }\end{array}$ & & & & & $-3.39 * *$ & -0.25 \\
\hline Constant & 0.13 & 0.44 & $-4.93 * *$ & $\mathrm{I} .45$ & -1.66 & 1.09 \\
\hline Number of observations & 2,249 & & 2,107 & & 2,249 & \\
\hline Pseudo $R^{2}$ & 0.51 & & 0.48 & & 0.63 & \\
\hline
\end{tabular}

*Significant at the .10 level.

**Significant at the .05 level (two-tailed tests).

the effect of similar changes in political instability (a 2 percent decrease), relative size of the group (a 6 percent decrease), and greater democracy (a 4 percent increase).

\section{The Effect of New Factions}

Each of the preceding analyses examines how the number of other factions (or the number of other factions using violence) affects the behavior of a faction in a given year. However, as indicated earlier, the conflict itself may also affect fragmentation, making endogeneity a potential problem. Here, we examine whether the addition of a faction in the previous year influences the behavior of the other factions. Table 5 presents a set of models on all our dependent variables with the entry of a new faction in the previous year as the independent variable. Because the effect of adding a new faction should have a greater impact when groups are more cohesive, we interact whether a faction entered in the previous year with the number of factions in the group. 
These tests indicate that the addition of another faction (whether violent or not) increases the probability that each individual faction will use violence against the state, target other co-ethnic factions, and use violence against coethnic civilians. The positive and significant coefficient on a new faction entering in the previous year indicates that new competition increases the chance of violence for any particular faction in a given year. The negative interaction term between this and the number of factions suggests that this conflict promoting effect decreases as there are a greater number of other factions. For instance, if a new faction enters a dispute with four factions (the first quartile of values), the likelihood that a particular faction will use violence in the larger dispute in a given year increases by 4 percent. The conflict promoting effect of a new faction decreases as the number of factions increases. The interpretation of the significance for the constituent terms in the interaction, however, must be examined beyond the significance reported in the model (Braumoeller 2004). Graphing the effect of a new faction across the range of the number of factions, we see that effect of a new faction becomes statistically insignificant at six factions at the .05 level and at eleven factions at the .10 level.

Models 2 and 3 also show a positive and significant relationship between the entrance of a new faction and the probability that a particular faction will target co-ethnic factions or civilians. The interaction terms are negative and significant - the effect of a new faction entering the fray diminishes at higher numbers of factions in the group, though this conditional effect is predominantly at the extreme values. At both the first and the third quartiles (four and ten factions, respectively), the entry of a few faction leads to an 8 percent increase in the likelihood of a faction targeting other co-ethnic factions. At the highest number of factions, a new faction produces a 5 percent increase. Similarly, the entry of a new faction in the previous year produces a 4 percent increase in the chance of a particular faction targeting co-ethnic civilians in a given year (holding the number of factions at four) and decreases slightly as the number of factions in the group increases. The effect of a new faction remains statistically significant across most of the values on the number of factions (dropping below .05 at twenty factions for model 2 and twelve factions for model 3). The other control variables return similar results to the earlier models.

The results here should alleviate, to some extent, the concerns about endogeneity. It is possible that there is something about conflicts with more violence against the state, more factional fighting, and more targeting of co-ethnic civilians that causes groups to become more fragmented over time. However, these analyses show that when a new faction joins the dispute in one year, the existing factions are more likely to use violence against the state, against other factions, and against co-ethnic civilians in the next year. These findings suggest that the increase in competition due to fragmentation leads to violence rather than the opposite. 


\section{Discussion}

We argue that the politics of self-determination are driven by two contests - that between the state and the group, and that between factions within the group. Nearly all large- $N$ studies examine only factors related to the first contest. Our analyses, concentrating on the neglected politics of factionalism, show strong support for this dual contest framework by underscoring the importance of fragmentation. We find that factions in more fragmented groups are much more likely to use violence in their struggle against the state, and are more likely to attack one another and co-ethnic civilians than when self-determination groups are more cohesive. In this section, we discuss the implications of these findings and address other issues that emerge from the analysis.

A key premise in our study is that something is lost when we ignore fragmentation of self-determination groups. Of course, the unitary actor assumption is only problematic if actor fragmentation affects the outcomes we are interested in explaining. Here, we have shown that fragmentation matters - and has statistically significant effects - in a number of key contexts. Moreover, if we compare the size of the effect to other predictors of violence, we find that fragmentation is substantively important. Fragmentation has an equivalent or larger effect than other significant variables in most of our models.

When we compare the findings regarding the effect of the number of other factions present in the group to the number of other violent factions in the group we see more consistently significant effects from a proliferation of violent factions. This is consistent with our logic of internal competition if the use of violence by factions generates a more intense struggle internally. It does suggest, however, that factions play different roles in the second contest-for political relevance-depending on whether they are willing to use violence. We think this is likely to be related to the different ways that factions can maintain and achieve political relevance. We argue that political relevance can come from above (i.e., from recognition by the state government) or below (i.e., creating a strong support base and marginalizing rival factions). The fact that states can recognize factions through negotiations and thus confer political relevance on them means that we should not ignore weak or nonviolent factions, as politically relevance does not rely solely on military might or power. Yet, because state decisions that create this kind of political relevance can occur at any time and with any faction, factional competition may center more around those factions that are able to create relevance from below-that is, the factions that impose costs through violence.

Additionally, our analysis reveals interesting effects of democracy. Shifts toward higher levels of democracy seem to encourage factions' use of violence against co-ethnics factions and civilians. This is consistent with other findings about the relationship between shifts in regime type and civil war (Mann 2005; Mansfield and Snyder 2005; Cederman, Hug, and Krebs 2010). It is likely that there is a proliferation of factions organized as political parties during democratic transitions, which would lead us to expect to see a growing number of 
factions pursuing self-determination through peaceful means. Yet, we find that increases in the level of democracy are associated with more factional fighting. Taken together, these dynamics suggest that new competitors matter-especially to other factions - but that they may turn to violence very quickly (Snyder 2000). More information about how factions emerge and behave in transitioning countries or other contexts in which political behavior becomes less regulated could shed more light on this question. ${ }^{12}$ Moreover, the debate around anocracy and civil war, where many of the findings appear to be driven by Polity 2's inclusion of political violence between rival factions rather than political institutions (Vreeland 2008), would benefit from closer attention to the factional politics of divided groups.

Competition between factions matters a great deal for the larger dispute over the so-called master cleavage. In this study, we have largely bracketed the first level of competition - that between the group and the state. However, the role of the state is essential. When the resources of self-determination group factions are diverted from challenging the state to challenging their co-ethnics, the state faces a dilemma. If the state officially recognizes new factions, competition between them may heighten and lead to factional fighting over political relevance. But, if such infighting diverts resources away from challenging the state, it could be seen as advantageous for states on the whole.

There are two important ways that the interaction between the state and the group should affect factional behavior. First, if the state is accommodating the group, it may influence how factions choose to engage the state, as the state is potentially creating avenues of "conventional politics" for the factions" demands. If, in contrast, the factions are discontent with the state's accommodation attempts, the result could be greater interfactional violence. Second, the state's use of violence against a challenging group should influence the group's cohesion (see McLaughlin and Pearlman in this issue). Cunningham (2011), however, shows that even controlling for concessions from states, more divided self-determination group are more likely to be involved in civil war with the state. These two factors - concessions from the state and civil war between the group and state - account for some major aspects of the larger dispute. However, they do not fully capture the strategic interaction between states and factions, especially with respect to the competition between factions for political relevance. Information about how and why states chose to negotiate with factions would enhance our understanding of the strategic behavior of states and factions as they interact in the larger dispute.

Our findings suggest that much is lost in the commonplace convention of assuming that the "incompatibilities" being fought over in separatist wars are dyadic, that is, between ethnic groups and the states they challenge. Instead, the interfactional contest for political relevance within the broader self-determination movement is an important determinant for the probability of violence and its contours. Attempts to broaden existing data sets to include faction- and organization-specific variables, 
as well as the construction and expansion of original data sets such as the one used here, are crucial to the advancement of the study of conflict.

Our general findings confirm many of the observations that have emerged in recent qualitative literature on fragmentation. These case studies have contributed much to our understanding of fragmentation in specific contexts, but it is also important to examine which dynamics apply more generally across groups and which are limited to specific cases. This is the major contribution of our dual-contest framework and the large-n tests of its implications. Progress in the fragmentation research program, where key concepts, measures, and hypotheses are still being formed, is likely to rely heavily on such triangulation between large- $N$, formal models, and case study approaches.

Finally, these findings have policy implications, suggesting that interventions and efforts aimed at conflict resolution need to consider intragroup dynamics as much as intergroup dynamics. If, as we find, violence in separatist struggles is driven by dynamics within the challenging groups (as well as between the challenger and the state), conflict prevention and peace building are as much about dynamics within groups as between these groups and the states they challenge. In terms of concrete initiatives, interventions should pay greater attention to mediation, negotiation, and peace building within fragmented groups as an important complement to efforts to promote peace between governments and separatist challengers. Moreover, our findings have important implications for the plight of civilians in war zones. Indeed, to the degree that interfactional contests increase the targeting of co-ethnic civilians, civilians can have as much reason to fear the factions that represent them as they do the state.

\section{Acknowledgments}

The authors would like to thank Meia Nouwens, Veerle Nouwens, and Mike Kostboth for their excellent research assistance, as well as Aoife McDonnell, Dian Mutmainah, Sanne Nolet, Kang Sookyoung, Kate Tennis, and Franzisca Zanker for their contributions to the data collection. The project has benefited greatly from feedback and conversations with David Cunningham, Fotini Christia, Monica Duffy Toft, Kristian Gleditsch, Ragnhild Nordås, Idean Salehyan, Steve Saideman, Paul Staniland, Wendy Pearlman, and the participants at the CSCW/PRIO seminar in Oslo in May 2010, and panels at International Studies Association (ISA) and American Political Science Association (ASPA) 2009. The authors would also like to thank ISA for their Catalytic Workshop Grant. Replication data are available at http:// jcr.sagepub.com/.

\section{Declaration of Conflicting Interests}

The author(s) declared no potential conflicts of interest with respect to the research, authorship, and/or publication of this article.

\section{Funding}

The author(s) received no financial support for the research, authorship, and/or publication of this article. 


\section{Notes}

1. The MAR project, in contrast, has begun to disaggregate groups in the Middle East and North Africa (MAR 2010).

2. See the data appendix for the process through which groups were selected.

3. To create the logged number of factions, we added one to all values before logging it. This is because some observations have no other factions, or no other factions using violence. We code the use of violence from new reports via Keesing's Record of World Events and Lexis Nexis new sources.

4. To code these, we rely on reports from Keesing's and Lexis Nexis news sources that attribute violence directly to the faction.

5. Ideally, we would control for factors known to affect factional behavior, yet little disaggregated research has been done to suggest what the appropriate variables are. Instead, we include variables related to fragmentation and violence in the overall dispute, with the assumption that the chance of any one faction contributing to violence at the faction level should be related to the dynamic of conflict at the dispute level as well.

6. There is limited variation on this variable, which we draw from the MAR project, in our sample. The groups range from "a majority living in a territory" (GROUPCON $=2)$ to groups that are "concentrated" in a territory (GROUPCON =3). This is not surprising given that these groups have already mobilized to demand self-determination in order to get into the sample, but we need to be aware of the restricted range of this variable in interpreting the results.

7. This is an average of the years where data are available from MAR, supplemented by data from Cederman, Min, and Wimmer (2009).

8. These "group governments" are coded by the authors and are not included as independent factions in the data set.

9. We ran another set of models including a series of other control variables that are frequently associated with civil war for all tables presented here. All but one of the models with significant findings on fragmentation are robust to the inclusion of logged gross domestic product (one year lag), logged country population (one year lag), logged mountainous terrain, and a dummy variable for oil exporting country. Model 2 in Table 2 is the exception. The sign is similar but the standard error is larger, making it insignificant at conventional levels.

10. All predicted probabilities are calculated using Clarify, holding all other variables at their mean for continuous variables, median for ordinal variables, and mode for categorical variables (King, Tomz, and Wittenberg 2000).

11. Figure 1 shows predicted probabilities for the bulk of the data (the first through third quartiles). The predicted probability of factional fighting continues to increase at the largest values of the variables, but we have excluded these to make the graph easier to read.

12. The link between democracy and violence remains controversial in the literature (Treier and Jackman 2008; Narang and Nelson 2009; Cederman, Hug, and Krebs 2010). 


\section{References}

Alesina, Alberto, and Enrico Spolaore. 2003. The Size of Nations. Boston, MA: MIT Press.

Bakke, Kristin M. 2010. "The Turn to Violence in Chechnya and Punjab: Self-Determination Struggles in Decentralized States." In Rethinking Violence: States and Non-State Actors in Conflict, edited by Adria Lawrence and Erica Chenoweth. Cambridge, 221-240. MA: MIT Press.

Beck, Nathaniel, Jonathan N. Katz, and Richard Tucker (1998). “Taking Time Seriously in Binary Time-Series Cross-Section Analysis." American Journal of Political Science 42 (4): 1260-88.

Beissinger, Mark R. 2002. Nationalist Mobilization and the Collapse of the Soviet State. New York: Cambridge University Press.

Bennett, D. Scott. 2008. "Governments, Civilians, and the Evolution of Insurgency: Modeling the Early Dynamics of Insurgencies." Journal of Artificial Societies and Social Simulation 11 (4).

Bhavnani, Ravi, and Michael Ross. 2003. "Announcement, Credibility, and Turnout in Popular Rebellions.” Journal of Conflict Resolution 47 (3): 340-66.

Bloom, Mia M. 2004. "Palestinian Suicide Bombing: Public Support, Market Share, and Outbidding." Political Science Quarterly 119 (1): 61-88.

Braumoeller, Bear. 2004. "Hypothesis Testing and Multiplicative Interaction Terms." International Organization 58 (4): 807-20.

Cederman, Lars-Erik. 2008. "Articulating the Geo-Cultural Logic of Nationalist Insurgency." In Order, Conflict, and Violence, edited by Stathis Kalyvas, Ian Shapiro, and Tarek Masoud. Cambridge, MA: Cambridge University Press.

Cederman, Lars-Erik, Simon Hug, and Lutz F. Krebs. 2010. "Democratization and Civil War: Empirical Evidence.” Journal of Peace Research 47 (4): 377-94.

Cederman, Lars-Erik, Brian Min, and Andreas Wimmer. 2009. "Ethnic Power Relations dataset," hdl:1902.1/11796 UNF:5:k4xxXC2ASI204QZ4jqvUrQ==.

Collier, Paul, and Anke Hoeffler. 2004. "Greed and Grievance in Civil War." Oxford Economic Papers 56 (4): 563-95.

Crescenzi, Mark. 1999. "Violence and Uncertainty in Transitions." Journal of Conflict Resolution 43 (2): 192-212.

Cunningham, Kathleen Gallagher. 2011. "Divide and Conquer or Divide and Concede: How Do States Respond to Internally Divided Separatists?" American Political Science Review 105 (2): 275-297.

de Marchi, Scott. 2005. Computational and Mathematical Modeling in the Social Sciences. New York: Cambridge University Press.

Fearon, James D. 1995. "Rationalist Explanations for War." International Organization 49 (3): $379-414$.

Fearon, James D. 2004. "Why Do Some Civil Wars Last So Much Longer Than Others?" Journal of Peace Research 41 (3): 275-301.

Fearon, James D., and David D. Laitin. 2003. “Ethnicity, Insurgency, and Civil War.” American Political Science Review 97 (1): 75-90. 
Filkins, Dexter. 2008. The Forever War. New York: Knopf.

Findley, Michael, and Peter J. Rudloff. Forthcoming. "Combatant Fragmentation and the Dynamics of Civil War." British Journal of Political Science.

Gates, Scott, Håvard Hegre, Mark P. Jones, and Håvard Strand. 2006. "Institutional Inconsistency and Political Instability: Polity Duration, 1800-2000." American Journal of Political Science 50 (4): 893-908.

Gurr, Ted R. 2000. Peoples Versus States. Washington, DC: United States Institute of Peace Press.

Gurr, Ted R., and Monty Marshall, eds. 2003. Peace and Conflict: A Global Survey of Armed Conflicts, Self-Determination Movements, and Democracy. College Park, MD: The Center for International Development and Conflict Management.

Hegre, Håvard, Tanja Ellingsen, Scott Gates, and Nils Petter Gleditsch. 2001. "Toward a Democratic Civil Peace? Democracy, Political Change, and Civil War, 1816-1992." American Political Science Review 95 (1): 33-48.

Hegre, Håvard, and Nicholas Sambanis. 2006. "Sensitivity Analysis of Empirical Results on Civil War Onset.” Journal of Conflict Resolution 50 (4): 508-35.

Horowitz, Donald. 1985. Ethnic Groups in Conflict. Berkeley: University of California Press.

Humphreys, Macartan, and Jeremy Weinstein. 2006. "Handling and Manhandling Civilians in Civil War." American Political Science Review 100 (3): 429-47.

Johnston, Patrick. 2008. "The Geography of Insurgent Organization and its Consequences for Civil Wars: Evidence from Liberia and Sierra Leone." Security Studies 17 (1): 107-237.

Jok, Jok M., and Sharon E. Hutchinson. 1999. “Sudan's Prolonged Second Civil War and the Militarization of Nuer and Dinka Ethnic Identities." African Studies Review 42 (2): 125-45.

Judge, Paramjit Singh. 2005. Religion, Identity and Nationhood: The Sikh Militant Movement. New Delhi: Rawat.

Kalyvas, Stathis N. 2003. "The Ontology of 'Political Violence': Action and Identity in Civil Wars." Perspectives on Politics 1 (3): 475-94.

Kalyvas, Stathis N. 2006. The Logic of Violence in Civil War. New York, NY: Cambridge University Press.

Kaufman, Stuart J. 1996. "Spiraling to Ethnic War: Elites, Masses and Moscow in Moldova's Civil War.” International Security 21 (2): 108-138.

King, Charles, 2004. "The Micropolitics of Social Violence." World Politics 56 (3): 431-55.

King, Gary, Michael Tomz, and Jason Wittenberg. 2000. "Making the Most of Statistical Analyses: Improving Interpretation and Presentation." American Journal of Political Science 44 (2): 347-61.

Lichbach, Mark I. 1994. "What Makes Rational Peasants Revolutionary? Dilemma, Paradox, and Irony in Peasant Collective Action." World Politics 46 (3): 383-418.

Lyall, Jason. 2010. "Are Coethnics More Effective Counterinsurgents? Evidence from the Second Chechen War." American Political Science Review 104 (1): 1-20.

Mahoney, James, and Gary Goertz. 2004. "The Possibility Principle: Choosing Negative Cases in Qualitative Research." American Political Science Review 98 (4): 653-670. 
Mann, Michael. 2005. The Dark Side of Democracy Explaining Ethnic Cleansing. New York: Cambridge University Press.

Mansfield, Edward, and Jack Snyder. 2005. Electing to Fight: Why Emerging Democracies Go to War. Cambridge, MA: MIT Press.

MAR (Minorities at Risk Project). 2005. Minorities at Risk Dataset. College Park, MD: Center for International Development and Conflict Management, http://www.cidcm.umd.edu/mar.

MAR (Minorities at Risk Project). 2008. Minorities at Risk Organizational Behavior Dataset. College Park, MD: Center for International Development and Conflict Management, http://www.cidem.umd.edu/mar.

Marshall, Monty, and Keith Jaggers. 2008. Polity IV Project: Political Regime Characteristics and Transitions, 1800-2008. Center for Systemic Peace and George Mason University.

Narang, Vipin, and Rebecca Nelson. 2009. "Who are these Belligerent Democratizers? Reassessing the Impact of Democratization on War." International Organization 63 (2): 357-80.

Pearlman, Wendy. 2008/2009. "Spoiling Inside and Out: Internal Political Contestation and the Middle East Peace Process." International Security 33 (3): 79-109.

Popkin, Samuel. 1988. "Political Entrepreneurs and Peasant Movements in Vietnam." In Rationality and Revolution, edited by Michael Taylor, 9-62. New York: Cambridge University Press.

Posner, Eric. 2004. "The Political Salience of Cultural Difference: Why Chewas and Tumbukas are Allies in Zambia and Adversaries in Malawi." American Political Science Review 98 (4): $529-45$.

Powell, Robert. 1999. In the Shadow of Power: States and Strategies in International Politics. Princeton, NJ: Princeton University Press.

Rabushka, Alvin, and Kenneth Shepsle. 1972. Politics in Plural Societies: A Theory of Democratic Instability. Columbus: Merrill.

Regan, Patrick M., and Daniel Norton. 2005. "Greed, Grievance, and Mobilization in Civil Wars." Journal of Conflict Resolution 49 (3): 319-36.

Rothschild, Joseph. 1981. Ethnopolitics, a Conceptual Framework. New York: Columbia University Press.

Snyder, Jack. 2000. From Voting to Violence: Democratization and Nationalist Conflict. New York: Norton.

Stedman, Stephen John. 1997. "Spoiler Problems in Peace Processes." International Security 22 (2): 5-53.

Toft, Monica Duffy. 2003. The Geography of Ethnic Violence: Identity, Interests, and the Indivisibility of Territory. Princeton, NJ: Princeton University Press.

Toft, Monica Duffy. 2007. "Getting Religion: The Puzzling Case of Islam and Civil War." International Security 31 (4): 97-131.

Treier, Shawn, and Simon Jackman. 2008. "Democracy as a Latent Variable.” American Journal of Political Science 52 (1): 201-17.

Varshney, Ashutosh. 2002. Ethnic Conflict and Civic Life. New Haven, CT: Yale University Press.

Vreeland, James Raymond. 2008. "The Effect of Political Regime on Civil War." Journal of Conflict Resolution 52 (3): 401-25. 
Walter, Barbara F. 2006. "Building Reputation: Why Governments Fight Some Separatists but Not Others." American Journal of Political Science 50 (2): 313-30.

Walter, Barbara F., and Andrew Kydd. 2002. "Sabotaging the Peace: The Politics of Extremist Violence." International Organization 56 (2): 263-96.

Weinstein, Jeremy. 2007. Inside Rebellion: The Politics of Insurgent Violence. New York: Cambridge University Press.

Wood, Elizabeth. 2003. Insurgent Collective Action and Civil War in El Salvador. Cambridge, MA: Cambridge University Press. 